\title{
Hubungan Pengetahuan dan Sikap Ibu tentang Posyandu dengan Status Gizi Balita di Desa Gampong Baroe Kecamatan Peukan Bada
}

\author{
The Relationship between Knowledge and Attitudes of Mothers about Posyandu \\ with Nutritional Status of Toddlers in Gampong Baroe Village, Peukan Bada \\ District \\ Raudhatun Nuzul ZA. ${ }^{* 1}$, Cut Meri Juwita ${ }^{2}$ \\ ${ }^{1}$ Program Studi D-IV Bidan Pendidik, Universitas Ubudiyah Indonesia, Banda Aceh, Indonesia \\ ${ }^{2}$ Program Studi D-III Kebidanan, Universitas Ubudiyah Indonesia, Banda Aceh, Indonesia \\ *Korespondensi Penulis : raudhatun@uui.ac.id
}

\begin{abstract}
Abstrak
Posyandu yang merupakan pusat kegiatan masyarakat, dimana masyarakat sekaligus dapat memperoleh pelayanan keluarga berencana dan kesehatan di Desa Gampong Baro Kecamatan Peukan Bada Kabupaten Aceh Besar diperoleh data bahwa jumlah balita adalah sebanyak 97 orang dengan rincian balita yang mengalami gizi baik 79 orang, gizi kurus 11 orang, gizi kurang 3 orang dan gizi sangat kurus 4 orang. Bersifat analitik dengan pendekatan Cross Sectional. Pengambilan sampel dengan cara total sampling yaitu 97 responden, Pengumpulan data dilakukan dengan cara mengambil data sekunder. Dari hasil penelitian ini menunjukan bahwa dari 41 responden yang berpengetahuan cukup tentang posyandu terdapat 32 responden $(78 \%)$ mempunyai status gizi baik. ( $\mathrm{P}$ value $=0,211)$, sikap ibu 58 responden yang sikap ibu positif tentang posyandu terdapat 44 responden $(75,9 \%)$ mempunyai status gizi baik. $(P$ value $=1.000)$. Kesimpulan dan Saran :Tidak Ada hubungan pengetahuan dan sikap ibu tentang posyandu dengan Status Gizi Balita. Diharapkan ibu dapat memperoleh pengetahuan dan informasi tambahan mengenai status gizi balita sehingga ibu paham dan mendukung kegiatan posyandu dengan status gizi balita sehingga dapat mendukung pemenuhan gizi yang optimal bagi balita.
\end{abstract}

Kata Kunci : Pengetahuan, Sikap Ibu, Status Gizi

\begin{abstract}
Posyandu which is the center of community activities, where the community can also obtain family planning and health services In Gampong Baro Village, Peukan Bada Subdistrict, Aceh Besar Regency, data shows that the number of children under five is 97 people with details of children who have good nutrition 79 people, underweight 11 people, lack of nutrition 3 people and very thin nutrition 4 people. Method: Analytical with Cross-Sectional approach. sampling by means of total sampling is 97 respondents, data collection is done by taking secondary data. Results: From the results of this study showed that of 41 respondents who were well-informed about posyandu there were 32 respondents (78\%) who had good nutritional status. $(P$-value $=0.211)$, the attitude of the mother of 58 respondents who have a positive mother attitude about posyandu there is 44 respondents (75.9\%) who have good nutritional status. $(P$-value $=1,000)$. Conclusions and Suggestions: There is no relationship between knowledge and attitudes of mothers about posyandu with Toddler Nutrition Status
\end{abstract}


Suggestion: It is expected that mothers can obtain additional knowledge and information regarding nutritional status of children so that mothers understand and support the activities of posyandu with toddler nutritional status so that it can support optimal nutrition fulfillment for toddlers.

Keywords: Knowledge, Mother's Attitude, Nutritional Status

\section{PENDAHULUAN}

Tujuan utama pembangunan nasional adalah peningkatan kualitas Sumber Daya Manusia (SDM) yang dilakukan secara berkelanjutan. Upaya peningkatan kualitas SDM dimulai dengan usia dewasa muda. Pada masa tumbuh kembang ini, pemenuhan kebutuhan dasar anak seperti perawatan dan makanan bergizi yang diberikan dengan penuh kasih sayang dapat membentuk SDM yang sehat, cerdas dan produktif (Radiansyah, 2007).

Millenium Development Goals (MDG's) adalah upaya untuk memenuhi hak-hak dasar kebutuhan manusia melalui komitmen bersama antara 189 negara anggota PBB. Menurut data yang di tunjukkan oleh MDG's, angka malnutrisi (kekurangan gizi) bagi anak usia di bawah lima tahun pada tahun 1990 sebesar 35,5\% dan menurun pada saat ini sebesar 28,7\%. Target yang ingin di capai pada tahun 2015 sebesar 18\%. Hal ini mengharuskan pemerintah dan petugas kesehatan untuk terus berusaha lebih keras agar target yang telah di tentukan tercapai (Peter, 2008).

Posyandu yang merupakan pusat kegiatan masyarakat, dimana masyarakat sekaligus dapat memperoleh pelayanan keluarga berencana dan kesehatan. Disamping itu, posyandu dapat dimanfaatkan sebagai sarana untuk tukar pendapat dan pengalaman serta bermusyawarah untuk memecahkan masalah yang dihadapi masyarakat (Depkes RI, 2005).

Posyandu merupakan salah satu pelayanan kesehatan di desa untuk memudahkan masyarakat untuk mengetahui atau memeriksakan kesehatan terutama untuk ibu hamil dan anak balita. Peran aktif keluarga pada setiap kegiatan posyandu tentu akan berpengaruh pada keadaan status gizi anak balitanya, karena salah satu tujuan posyandu adalah memantau peningkatan status gizi masyarakat terutama anak balita dan ibu hamil (Adisasmito, 2008).

Sikap ibu balita untuk menyadari bahwa posyandu merupakan hal yang utama untuk meningkatkan derajat kesehatan balita, hal ini dapat menimbulkan perilaku positif ibu balita tentang posyandu, sehingga ibu bersedia untuk hadir ke posyandu, karena kehadiran ibu balita sangat mempengaruhi peningkatan derajat kesehatan ibu dan balita selain itu ibu dapat memantau tumbuh kembang balitanya dengan pengawasan dari petugas kesehatan. Sikap ibu 
balita yang positif akan mempengaruhi perubahan perilaku yang positif, sehingga ibu balita tidak berprasangka buruk akan pentingnya untuk hadir ke posyandu, karena perilaku adalah bentuk respon atau reaksi stimulus atau rangsangan dari luar organisme (orang) dan stimulus tersebut dapat di berikan dengan cara mengadakan penyuluhan-penyuluhan tentang posyandu kepada lapisan masyarakat, namun dalam memberikan respon atau stimulus sangat tergantung pada karakteristik atau faktor-faktor lain dari orang bersangkuatn yaitu faktor internal dan faktor eksternal. Bila sikap ibu balita tentang posyandu positif maka ibu balita akan hadir secara rutin ke posyandu tiap bulannya dan sebaliknya jika sikap ibu balita tentang posyandu negatif maka kehadiran ibu balita tidak akan rutin tiap bulannya. Hal ini berarti meskipun stimulus sama bagi beberapa orang, namun respon tiap orang berbeda (Notoatmodjo, 2007)

Kasus gizi Kurang Energi Protein (KEP) dan partisipasi masyarakat dalam kegiatan posyandu yang masih kurang, sehingga puskesmas mengalami kesulitan dalam mendata dan mengintervensi kasus. Jumlah balita yang datang ke posyandu sebanyak 61\%. Hal ini membuktikan partisipasi masyarakat masih sangat kurang terhadap posyandu. Salah satu kader posyandu menyatakan bahwa kejadian kasus gizi KEP pada balita sebenarnya masih banyak terjadi, namun peran aktif keluarga untuk memantau pertumbuhan dan perkembangan balitanya masih sangat kurang. Hal tersebut dapat dilihat dari cakupan penimbangan pada setiap posyandu yang diadakan setiap bulan yang masih dibawah $80 \%$ bahkan dibeberapa RW hanya mencapai sekitar 40\% (Puslitbang Gizi Bogor,2007) .

Data Depkes 2010-2011 jumlah kasus gizi buruk hingga saat ini masih memprihatinkan. Tercatat jumlah anak balita yang terkena gizi buruk melonjak dari 1,8 juta (2010) menjadi 2,3 juta anak (2011). Dalam kurun waktu tersebut, lebih dari lima juta balita tekena gizi kurang, bahkan 10\% berakhir dengan kematian (Bapeda Jabar,2006).

Kasus gizi buruk yang menimpa anak-anak dibawah umur 5 tahun (balita) juga terjadi di berbagai daerah di Jawa Barat. Status gizi balita di kabupaten Bandung pada tahun 2006 menunjukkan balita dengan status gizi kurang sebesar 1,31\% dan balita dengan status gizi buruk sebesar $0,92 \%$. Jumlah penderita, rata-rata naik di banding tahun sebelumnya (Profil Kesehatan Kab. Bandung Tahun 2006).

Status gizi merupakan keadaan yang dapat menggambarkan gizi seseorang apakah tergolong gizi baik, gizi kurang, gizi buruk, atau gizi lebih. Hasil Riset Kesehatan Dasar 2010, menunjukkan prevalensi status gizi balita $(\mathrm{BB} / \mathrm{U})$ di Indonesia yaitu gizi buruk sebesar 4,9\%, gizi kurang sebesar $13 \%$, gizi baik sebesar 76,2\%, dan gizi lebih sebesar 5,8\%. Prevalensi 
status gizi balita (BB/U) di Nanggroe Aceh Darussalam yaitu gizi baik sebesar 84,2\%, gizi kurang sebesar 13,2\%, gizi buruk sebesar 1,0\%, dan gizi lebih sebesar 1,6\% (Riskesdas, 2010).

Data Profil Kesehatan Provinsi Aceh (2015), menunjukkan prevalensi gizi di kabupaten Aceh Besar yaitu gizi baik sebesar 85,9\%, gizi kurang sebesar 13,4\%, gizi buruk sebesar 0,2\%, dan gizi lebih sebesar 0,6\% (Dinkes Provinsi Aceh, 2015). Sedangkan jumlah balita diwilayah kerja Puskesmas Puskesmas Peukan Bada Kabupaten Aceh Besar sebanyak 3.428 orang, yang menderita gizi buruk adalah sebanyak $18(0,89 \%)$ orang (Dinkes Aceh Besar, 2015)

Berdasarkan hasil pengambilan data awal di Desa Gampong BaroKecamatan Peukan Bada Kabupaten Aceh Besar diperoleh data bahwa jumlah balita adalah sebanyak 97 orang dengan rincian balita yang mengalami gizi baik 79 orang, gizi kurus 11 orang, gizi kurang 3 orang dan gizi sangat kurus 4 orang.

Oleh karena itu, peneliti tertarik untuk penelitian yang berjudul "Hubungan pengatahuan dan sikap ibu tentang posyandu dengan status gizi balita di Desa Gampong Baro Kecamatan Peukan Bada Kabupaten Aceh Besar”.

\section{METODE PENELITIAN}

Penelitian ini merupakan penelitian yang bersifat Analitik, dengan menggunakan pendekatan Cross Sectional yaitu suatu rancangan penelitian dengan melakukan pengukuran atau pengamatan pada saat bersamaan (sekali waktu).

\section{HASIL DAN PEMBAHASAN}

Tabel 1. Hubungan Pengetahuan tentang Posyandu dengan Status Gizi Balita di Desa Gampong Baro Kecamatan Peukan Bada Kabupaten Aceh Besar

\begin{tabular}{|c|c|c|c|c|c|c|c|c|}
\hline \multirow{3}{*}{ No } & \multirow{3}{*}{ Pengetahuan } & \multicolumn{4}{|c|}{ Status Gizi } & \multirow{2}{*}{\multicolumn{2}{|c|}{ Total }} & \multirow{3}{*}{ P-Value } \\
\hline & & \multicolumn{2}{|c|}{ Gizi Baik } & \multicolumn{2}{|c|}{ Gizi Kurang } & & & \\
\hline & & $\mathbf{f}$ & $\%$ & $\mathbf{F}$ & $\%$ & $\mathbf{f}$ & $\%$ & \\
\hline 1 & Baik & 32 & 78 & 9 & 22 & 41 & 100 & \\
\hline 2 & Cukup & 23 & 85,2 & 4 & 14,8 & 27 & 100 & 0,211 \\
\hline 3 & Kurang & 19 & 65,5 & 10 & 34,5 & 29 & 100 & \\
\hline
\end{tabular}


Berdasarkan tabel 1 menunjukkan bahwa dari 41 responden yang berpengetahuan cukup tentang posyandu terdapat 32 responden (78\%) mempunyai status gizi baik. Hasil analisa statistik menggunakan chi square test menunjukkan hubungan tersebut tidak bermakna dengan nilai $\mathrm{P}$ value $=0,211(\mathrm{p}>0.05)$ Dengan demikian dapat disimpulkan bahwa tidak ada hubungan antara pengetahuan tentang posyandu dengan status gizi balita di desa gampong baro Kecamatan Peukan Bada Kabupaten Aceh Besar

Tabel 2. Hubungan Sikap Ibu Tentang Posyandu Dengan Status Gizi Balita Di Desa Gampong Baro Kecamatan Peukan Bada Kabupaten Aceh Besar

\begin{tabular}{|c|c|c|c|c|c|c|c|c|}
\hline \multirow{3}{*}{ No } & \multirow{3}{*}{ Sikap } & \multicolumn{4}{|c|}{ Status Gizi } & \multirow{2}{*}{\multicolumn{2}{|c|}{ Total }} & \multirow{3}{*}{ P-value } \\
\hline & & \multicolumn{2}{|c|}{ Gizi Baik } & \multicolumn{2}{|c|}{ Gizi Kurang } & & & \\
\hline & & $\mathbf{f}$ & $\%$ & $\mathbf{f}$ & $\%$ & $\mathbf{f}$ & $\%$ & \\
\hline 1 & Positif & 44 & 75,9 & 14 & 24,1 & 58 & 100 & \multirow[b]{2}{*}{1.000} \\
\hline 2 & Negatif & 30 & 76,9 & 9 & 23,1 & 39 & 100 & \\
\hline
\end{tabular}

Menunjukkan bahwa dari 58 responden yang sikap ibu positif tentang posyandu terdapat 44 responden $(75,9 \%)$ mempunyai status gizi baik. Hasil analisa statistik menggunakan chi square test menunjukkan hubungan tersebut tidak bermakna dengan nilai $P$ value $=1.000(\mathrm{p}>0.05)$. Dengan demikian dapat disimpulkan bahwa tidak ada hubungan antara sikap tentang posyandu dengan status gizi balita di desa gampong baro Kecamatan Peukan Bada Kabupaten Aceh Besar.

\section{Pembahasan}

Berdasarkan tabel 4.4 menunjukkan bahwa dari 41 responden yang berpengetahuan cukup tentang posyandu terdapat 32 responden (78\%) mempunyai status gizi baik. Hasil analisa statistik menggunakan chi square test menunjukkan hubungan tersebut bermakna dengan nilai $P$ value $=0,211(\mathrm{p}>0.05)$ Dengan demikian dapat disimpulkan bahwa tidak ada hubungan antara pengetahuan tentang posyandu dengan status gizi balita di desa gampong baro Kecamatan Peukan Bada Kabupaten Aceh Besar.

Hasil penelitian sesuai dengan dengan penelitian yang telah dilakukan oleh Hartati dengan judul "Faktor-Faktor Yang Berhubungan Dengan Status Gizi Pada Balita Di Puskesmas Perembeu Kecamatan Kawai XVI Kabupaten Aceh Barat tahun 2013”. Total 
sampel dalam penelitian ini 169 balita. Menemukan bahwa tidak ada hubungan antara pengetahuan dengan status gizi balita dengan $\mathrm{p}$-value $=0,567$ di Puskesmas Perembeu Kecamatan Kawai XVI Kabupaten Aceh Barat tahun 2013.

Pengetahuan dapat membentuk suatu sikap dan menimbulkan suatu perilaku dalam kehidupan sehari-hari (Notoatmdjo,2007). Tingkat pengetahuan tentang posyandu pada kader kesehatanyang tinggi dapat membentuk sikap positif terhadap program posyandu khususnya pemanfaatan meja penyuluhan. Pada gilirannya akan mendorong seseorang untuk aktif dan ikut serta dalam pelaksanaan posyandu. Kurangnya pengetahuan sering di jumpai sebagai faktor yang penting dalam masalah pemanfaatan meja penyuluhan, karena kurangnya penyuluhan kesehatan sehingga pengetahuan anggota masyarakat khususnya ibu-ibu yang memiliki balita juga memiliki pengetahuan yang minim (Sediaotama, 2007).

Pengetahuan gizi yang baik akan menyebabkan seseorang mampu menyusun menu yang baik untuk dikonsumsi. Semakin banyak pengetahuan gizi seseorang, maka ia akan semakin memperhitungkan jenis dan jumlah makanan yang diperolehnya untuk dikonsumsi (Sediaoetama, 2006).

Menurut asumsi peneliti bahwa tidak ada hubungan antara pengetahuan tentang posyandu dengan status gizi balita, ibu yang memiliki pengetahuan yang baik tentang mengolah dan memberikan makanan yang bergizi untuk balitanya sangat berhubungan dengan status gizi balita tersebut. Dengan pengetahuan yang cukup dan memadai tentang gizi, maka balita yang di berikan makanan yang bergizi akan tumbuh menjadi balita yang memiliki status gizi yang normal.

\section{Hubungan Sikap Ibu Tentang Posyandu Dengan Status Gizi Balita}

Menunjukkan bahwa dari 58 responden yang sikap ibu positif tentang posyandu terdapat 44 responden $(75,9 \%)$ mempunyai status gizi baik. Hasil analisa statistik menggunakan chi square test menunjukkan hubungan tersebut bermakna dengan nilai $P$ value $=1.000(\mathrm{p}>0.05)$ Dengan demikian dapat disimpulkan bahwa tidak ada hubungan antara sikap tentang posyandu dengan status gizi balita di desa gampong baro Kecamatan Peukan Bada Kabupaten Aceh Besar Tahun 2015.

Hasil penelitian sesuai dengan dengan penelitian yang telah dilakukan oleh Hartati dengan judul "Faktor-Faktor Yang Berhubungan Dengan Status Gizi Pada Balita di Kecamatan Tamansari, Kabupaten Bogor.”.dari hasil uji chi square bahwa tidak ada 
hubungan antara sikap dengan status gizi balita dengan $p$-value $=0,661$ di Puskesmas di Kecamatan Tamansari, Kabupaten Bogor.

Sikap adalah reaksi tertutup dari seseorang terhadap stimulus atau objek, sikap mengambarkan suka atau tidak sukanya seseorang terhadap objek, sikap sering diperoleh dari pengalaman sendiri maupun dari orang lain. Seorang kader kesehatan yang mempunyai sikap yang utuh akan berpikir dan yakin dalam bertindak dan ikut serta untuk aktif memberikan motivasi kepada sasaran dan kegiatan posyandu.

Sikap merupakan reaksi atau respons yang masih tertutup dari seseorang terhadap suatu stimulus atau objek. Cardno dalam Notoatmodjo (2005) membatasi sikap sebagai hal yang memerlukan peredisposisi yang nyata dan variabel disposisi lain untuk memberi respons terhadap objek sosial dalam interaksi dengan situasi dan mengarahkan serta memimpin individu dalam bertingkah laku secara terbuka Menurut Notoatmodjo (2005), menyatakan bahwa sikap merupakan kesediaan dan kesiapan untuk bertindak dan bukan merupakan pelaksanaan motif tertentu, akan tetapi sebagai salah satu peredisposisi tindakan untuk prilaku. Sikap secara nyata menunjukkan konotasi adanya kesesuaian reaksi terhadap stimulus tertentu yang dalam kehidupan sehari-hari merupakan reaksi yang bersifat emosional.Sedangkan Krech et al dalam Notoatmodjo (2005) menyebutkan bahwa sikap menggambarkan suatu kumpulan keyakinan yang selalu mencakup aspek evaluatif sehingga selalu dapat diukur dalam bentuk baik dan buruk atau positif dan negatif.

Menurut asumsi peneliti bahwatidak ada hubungan antara sikap tentang posyandu dengan status gizi balita ibu yang memiliki sikap positif akan kencenderung akan berpikir yang baik dan yakin memberikan makanan yang bergizi untuk balita supaya balita sehat, sikap bisa diperoleh dari informasi di dalam kegiatan posyandu yang diadakan dengan adanya informasi ibu akan lebih meningkat pengetahuannya.

\section{KESIMPULAN}

Berdasarkan hasil penelitian yang telah dilakukan maka penelitian dapat mengumpulkan hasil dari penenelitian sebagai berikut :

1. Tidak ada hubungan antara sikap tentang posyandu dengan status gizi balita di desa gampong baro Kecamatan Peukan Bada Kabupaten Aceh Besar, dengan nilai $P$ value= $0,221$ ( $p>0.05)$. 
2. Tidak ada hubungan antara pengetahuan tentang posyandu dengan status gizi balita di desa gampong baro Kecamatan Peukan Bada Kabupaten Aceh Besar, dengan nilai $P$ value $=1,000(\mathrm{p}>0.05)$.

\section{SARAN}

Dengan selesainya penelitian ini di harapkan dapat menambah referensi kepustakaan atau sebagai acuan dalam mengadakan penelitian dimasa yang akan datang khususnya tentang status gizi.

\section{DAFTAR PUSTAKA}

Atikah (2009). Gizi Untuk Kebidanan Cetakan Pertama Penerbit Nuha Medika

Almatsir, (2009).Gizi Untuk Kebidanan Cetakan Pertama Penerbit Nuha Medika

Adisasmito.(2008). Catatan perkembangan posyandu.Diakses dari http://arali2008. wordpress.com/2009/04/20/catatan-ringan-tentang-perkembangan posyandu/.

Budiarto.(2009). Biostatistik untuk kedokteran dan Kesehatan masyarakat. Jakarta: EGC

Bapeda Jabar. (2006) Status Gizi Buruk Di Jabar. Dikutip dalam http://www.depkes_jabar.go.id(tanggal 21 Januari 2015)

Dinkes Aceh. (2013). Hasil Survei data dukung gizi provinsi nanggroe aceh darussalam tahun 2013.

Depkes RI. (2005). Balita BGM. http//:www.bank.data.depkes.go.id. 2010. Buku Ajaran Gizi untuk Kebidanan. Jogjakarta: Nuha Meidka

Hasdi.(2009). Revilitasi posyandu.Diakses dari http://skripsifkm.blogspot.com/2009/04/revitalisasi-posyandu_25.html.pada tanggal 04 Februari 2015.

Kemenkes RI, Direktorat Bina Gizi.(2011). Standar antropometri penilaian status gizi anak. Jakarta

Khairunisa, (2013), Hubungan peran aktif ibu dalam kegiatan posyandu dengan status gizi balita di wilayah kerja Puskesmas Kuta Baro Aceh Besar

Notoatmodjo, S. (2005). Metodelogi Penelitian Kesehatan. Jakarta: Rineka Cipta

Notoatmodjo, S. (2007). Pendidikan dan perilaku kesehatan, Jakarta: Rineka Cipta

Maulana, (2009) Hubungan Keaktifan Ibu Dalam Posyandu Dengan Penurunan Jumlah Balita Bawah Garis Merah (Bgm) Di Desa Suko Jember Kecamatan Jelbuk Kabupaten Jember.

Profil Kesehatan Kab.Bandung Tahun (2006) Gizi Bayi dan Balita. Dikutip dalam http://www.puslitbangbandung.go.id (Tanggal 23 Januari 2015) 
Pulisbang Gizi Bogor, (2007).kejadian kasus gizi KEP, Bogor.

Proverawati, (2009). Gizi Untuk Kebidanan Cetakan Pertama Penerbit Nuha Medika

Radiansyah. (2007) Gizi Balita dalam http://www.radiansyah.com/gizi/balita (dikutip tanggal 30 Januari 2015)

Syakira.(2009). Tentang posyandu.Diakses dari http://syakira-blog.blogspot.com /2009/01/ tentang-posyandu.html.

Sediaoetama.(2006) Gizi.Jakarta: Rineka Cipta , Jakarta

Suparianto. (2012) Konsep Dasar Status Gizi Balita: dikutip dalam http://blogspot.com (tanggal 21 Januari 2015)

Ulie Midwife.(2012). “ Posandu sebagai Saran Peran Serta Masyarakat dalam Usaha Peningkatan Kesehatan Masyarakat". Makalah. Universitas 